\title{
On the "Garden of Delights" as a MOdel of ANAlysis OF THE INTERCULTURAL COMMUNICATION PROCESSES
}

\author{
Lurdes Macedo
}

\begin{abstract}
The observation of Hieronymus Bosch's "Garden of Delights" triptych is the starting point for a short essay on the possible interpretation of this work by its last purchaser, Filipe II of Spain. Additionally, this essay leads to the proposal of a model, based on three categories of analysis, for the critical interpretation of the global course that humanity has been taking since the beginning of the great intercontinental navigations, initially carried out by the Portuguese and the Spanish. The proposed model intends to contribute to the defragmentation of the memory of a long process marked by the tension between hegemonic forces and dynamics of interculturality.
\end{abstract}

\section{Keywords}

Defragmentation of memory; globalization; intercultural communication

\begin{abstract}
Resumo
A observação do tríptico "Jardim das Delícias", de Hieronymus Bosch constitui o ponto de partida para um curto ensaio sobre a possível interpretação desta obra por parte do seu último comprador, Filipe II de Espanha. Por sua vez, este ensaio conduz à proposta de um modelo, baseado em três categorias de análise, para a interpretação crítica do percurso global que a humanidade tem vindo a trilhar desde o início das grandes navegações intercontinentais, inicialmente levadas a cabo por portugueses e espanhóis. O modelo proposto pretende constituir um contributo para a desfragmentação da memória de um longo processo marcado pela tensão entre forças hegemónicas e dinâmicas de interculturalidade.
\end{abstract}

\section{Palavras-chave}

Comunicação intercultural; desfragmentação da memória; globalização

\section{INTRODUCTION: FROM THE “GARDEN OF DELIGHTS" TO THE DIVERSITY OF THE WORLD}

Contemplating the triptych "Garden of Delights", by Hieronymus Bosch - currently in exhibition at the Prado Museum in Madrid - the observer is facing one of the most suggestive works of $16^{\text {th }}$ century art. According to several experts, although it is not clear when this "Garden of Delights" was painted, Bosch has devoted himself to this work in an indeterminate period between 1500 and 1505 (Portús, 2008).

Inspired by iconographic sources so different such as religion, alchemy, esotericism or fantastic imaginary, the painting is composed of three distinct but interconnected panels. It presents a complex narrative which has aroused the most diverse interpretations over the last five centuries, as Bosing (2003) has pointed out. 
As in other works of the author's maturity period, this triptych has a rare virtue when compared with the painting of this period: it combines the medieval tradition of Flemish painting of the fifteenth century, based on balance and harmony, with the modern sensibility of the sixteenth century, predisposed to the awakening of spirituality and reason (AAVV, 2006). Therefore, this is a work inscribed in an edge period, in which a new approach to pictorial representation can be observed. Thus, in the early 16 th century, Bosch's art was considered extravagant and its audience was circumscribed "to an elite with the necessary training to interpret it" as stated by Portús (2008, p. 320).

Educated as a true Renaissance prince, Filipe II soon became an erudite and curious man (Magalhães, 1993). He rapidly realized the painter's intellectual dimension associated with the excellence of his art and acquired, among other Bosch's works, this "Garden of Delights", taking it to the Escorial in 1593. Considering, as Mukarovsky (1997) proposed, that art can be comparable to a dialogue between author and the spectator, let us look at this work, perpetuated by the continuous efforts of interpretation along the time, taking into account the enigmatic interaction between the brilliant painter of imaginaries and the planetary dimension king.

The triptych begins by displaying, on the back of the mobile panels, when closed over the center panel, The Creation of the World in a representation of its third day. Once the mobile panels are opened, form under which the piece is exposed to the public, the narrative proceeds with an image of Paradise in front of the left panel. In an idyllic setting, the Creator, here represented more jovially than in other Bosch paintings, introduces Eve to Adam. According to the Holy Scriptures, this was the moment when God blessed the first human couple with the commandment: "be fruitful and multiply. Fill and subdue the Earth!" (Genesis, 1, 28). So, we are observing a primordial God's will: departing from Adam and Eve love relationship, the human race would reproduce and spread all over the planet as guarantee to a widely populous world.

The central panel is fixed and, at the same time, the biggest one. It represents the garden of earthly delights, where some groups of naked human figures delight in an erotic scene full of a strong symbolism. The painting is dominated by a wide spatiality as if the figures could be observed as in an inflight view. It should be noted that this form of space representation constitutes an exception in the artistic scenery of the time.

At the center of the composition is the fountain of youth, represented as a circle, where a group of numerous Caucasian women with different skin tones, as well as some black women, are bathing. The circular form of the fountain of youth is reinforced by the disposition of the knights who surround it. These men, riding animals as different as horses, bears, wild boars, camels, tigers and ostriches - always represented under the sign of the fantastic - carry fish and wild fruits of extraordinary dimensions. It should be noted that these two elements, which we believe to represent symbols of carnal pleasure in the Flanders of Bosch's time, are found all over the panel.

Above the fountain of youth we can find a great lake called adultery fountain. At the center of this fountain, on a huge grey globe, shameless characters engage in lascivious acrobatics. Human figures, mostly white but also some black, as well as fantastic 
figures, bath in this fountain while having fun in aquatic games. The adultery fountain is surrounded by unbelievable buildings and vegetable elements, standing out green bushes, which create an identical environment to those that can be observed in the surrealist painting of the twentieth century. Hence, authors such as Quina (2005) affirm that the "Garden of Delights" was a work of reference for artists involved in contemporary counter-naturalistic and surrealistic currents.

The lower part of the garden of earthly delights is occupied by groups of men and women. Some of them are engaged in loving games, some others are dedicated to the harvesting and tasting of oversized red fruits, all of them are freely and unabashedly enjoying the moment. Among the characters, mainly Caucasian, can be observed once again some blacks. On the left, in an aquatic setting, we can observe couples in love starring improbable scenes: one of them dates inside a crystal sphere'; Another navigates in a huge shell while trying to subtract a giant mulberry to a group dedicated to playful games; Another couple seems to dance with their legs dipped in the water; Finally, a couple of white men and a black woman kiss each other, while riding a mallard. In this regard, Portus (2008, p. 321) points out that the traveller Antonio de Beatis, in 1517, referred to the figures of this panel, as "such pleasant and fantastic things that in no way could be described to those who have not seen them".

Despite the chaotic disposition of the characters in this central panel, the painting is traversed by a vertical axis that divides the scene into two similar parts, giving it a sense of proportion. The bright colors and the carefree ambience in which the whole scene is represented complete the harmony that characterizes the garden of earthly delights.

In fact, the central panel configures the fulfillment of the commandment that God enunciates in Eden while introducing Eve to Adam. So, it seems also to give continuity to the left-hand panel: the quantity and variety of people and animals, as well as natural and architectural elements, ideally distributed throughout the length of this part of the triptych can be interpreted as a representation of a harmonious world.

The front of the right-hand panel - with the same dimension as the left-hand panel - presents, according to Bosing (2003), the most violent Hell's representation from those painted by Bosch. In a nightmare scenario, one can see, in the background, buildings that explode and burn illuminated by strange phosphorescence. In the foreground, men and women without any clothing on their bodies are tortured with huge objects of daily use. In this panel, dominated by representations of distress and suffering, "the atmosphere could not be more demonic", as Quina (2005, p. 360) observes.

Although its meaning may not be clear, and the many interpretations attributed to the Garden of the Delights - Man letting himself be carried away by the pleasure of senses, abandonment to the erotic experience, or madness of the world going on to ruin and perdition -, the acquirement of this painting by Phillip II for his remarkable art collection detracts from credibility explanations on its deliberate heretical representation. As noted by Hofstätter \& Pixa (1987), the king was catholic and Church protector.

'According to some interpreters of art piece, this couple illustrates the Netherlands' proverb "Pleasure is fragile as glass" (AAVV, 2006). 
Nowadays, accompanying the exhibition of this triptych in Prado Museum, there is an inscription that reveals the reason why the sovereign appreciated so much the "Garden of Delights": according to his interpretation, this painting represents the diversity of the world.

\section{THE DIVERSITY OF THE WORLD UNDER THE RULE OF FILIPE II}

Joly (1999) emphasized the need to put ourselves on the receiving position when we want to analyse a message, once the author's intentions are not clear for interpretation: first, because, strictly speaking, nobody knows enough about of what the author meant; second, because we cannot be certain that what we understand corresponds to the idea initially formulated escaping definitive conclusions; finally, because it is impossible for the author himself to control all the meaning produced by his message. Thus, the interpretation of a piece of art must focus on the meanings instigated in certain circumstances, rather than seeking to find out the pre-existing message.

Therefore, let us place ourselves on the side of the receiver, in this case Filipe II, relating his personal profile to the historical conditions in which his long reign (1555-1598) developed, so as to reveal a probable framework of meanings for his interpretation of the "Garden of Delights".

A controversial historical figure, about whom the best and the worst has been said, Philip II was, in his time, one of the most well informed men about the diversity of the world he recognized in Bosch's painting. Lord of an empire where there was no sun setting, he exercised sovereignty over people from very different cultures in the most diverse parts of the globe. The extension of his reign was explained because,

as his father's heir, King Charles $\mathrm{V}$, he reigned over the Iberian crowns of Aragon and Castile, which made him lord of the viceroys of New Spain (Mexico) and Peru, with other territories of Europe, such as Lombardy, Sicily, Naples, Sardinia, Franche-Comté and the Netherlands. The ascension to the throne of the Avis in 1580 brings with it the aggregation of Portugal and its overseas empire, facts that contributed to widespread his monarchy to an even more universal scale; Stretched from Europe to America, and from Africa to Asia. (Bouza, 2005, p. 16)

The interest of the monarch in the different geographies of his empire is denounced not only for having spent significant periods of time in all his domains in Europe, but also for the content of the correspondence he exchanged with various interlocutors. As an example, Bouza (2005) highlights the letters sent by Filipe to his daughters - the princesses Isabel Clara Eugenia and Catarina Micaela - who had stayed in Madrid during the two years he spent in Portugal (1581-1583). In these, the sovereign describes what he sees, what happens to him, what awaits him or surprises him, as is the case with devils - a kind of scarecrow - who went out during the Procession of Corpus Christy. As he narrated, these devils inspired Filipe as Hieronymus Bosch figures because they looked 
good and did not frighten him. From this allusion, it is possible to understand the importance assumed by the artist as an aesthetic reference of Filipe II and his family, as well as the influence that his work had on the monarch's imaginary.

Not having visited his vast domains outside Europe, what would have seemed impossible at the time, Philip II also had a large amount of information, through written documents, about the strange people who inhabited them, as well as their original life habits or their peculiar religious practices. Magalhães (1993, p. 564) affirmed on this facet of Filipe II: "expert in Geography seeks to know in detail the lands he governs, committing himself to take the right decisions" (sic). In fact, his imaginary was dominated by a broad and diverse conception of the world which the sovereign recognizes in the extraordinary spatiality of Bosch's central panel, in the exoticism of the interethnic relationships represented therein, and in the splendor of its natural and architectural elements ${ }^{2}$.

As Mukarovski (1997) noticed, in his reflections on aesthetics, the relation between art and conception of the world, even if traditionally considered simple and clear, needed a deep revision. This was true because the conception of the world can mean not only the spontaneous attitude that man assumes towards reality, in a certain geographic space and in a certain period of history, but it can also represent an ideology or even a philosophical system. The author concluded that this distinction is no doubt useful for the establishment of three different categories of approach to the relation between art and conception of the world - the noetic approach, the ideological approach and the philosophical approach - but should not be strictly adopted, under disadvantage of analysis impoverishment. He stated this idea because we are talking about an analysis of a connection in which the three dimensions merge into one whole.

In fact, Filipe II's conception of the world cannot be fully understood if we reduce it to his personal attitude to a different reality that he seemed to admire in Bosch's piece of art. It is Magalhães (1993, p. 564) who refers to the "structural diversity of their kingdoms and landlords, cities and towns and social groups" as an obstacle to the exercise of absolute power by the monarch. As Bouza (2005) observes, the territorial dispersion of his domains required the integration of a very different socio-cultural spaces in the same monarchy. So, the capacity to adapt to different local balances proved to be a determinant condition for strengthening the legitimacy of Filipe II government. According to the same author, Philip II, through the adoption of this convenient political strategy, relates his governance: "with the definitive globalization of the European presence on the planet or, in short, with the full consolidation of some cultural means and forms at the service of communication and the diffusion of news, ideas and opinions" (Bouza, 2005 p. 17). Indeed, as Magalhães (1993, p. 563) observed, no other sovereign of the modern age has ever had such great authority as Filipe II, "lord of vast territories that force him to various policies according to times and places" exercising "his royal mandate, believing he could do and rule everything, under God's approval" (Magalhães, 1993, p. 564). From

\footnotetext{
${ }^{2}$ It is good to remind that, at the time, the reports of the "new worlds" caused such strangeness, that the elements composing these narratives seemed fantastic or spectacular. Examples of this were the works written by the Spaniards Amerigo Vespucci and Cabeza de Vaca or by the Portuguese Fernão Mendes Pinto.
} 
these facts arises an integrationist philosophy that reveals another prism of analysis that we must admit to understand Filipe II's conception of the world. Thus, the diversity expressed through exoticism, originality and singularity as in the "Garden of Delights" is the same diversity with which the sovereign seeks to substantiate the immensity of his empire.

However, Filipe's power could never have been so extensive if he had not assumed the governance of all the diversity on which the Portuguese crown was based. After the disappearance of Sebastian, the Portuguese king of whom he was a cousin, at the Battle of Alcácer Quibir in 1578, "he soon made the necessary arrangements to introduce himself as inheritor (...) choosing a dedicated ambassador to begin in Lisbon the difficult power games that would be expected, because the Portuguese 'natural hatred' to Castile" (Magalhães 1993, p. 564). To be successful, he guarantees the support of the Society of Jesus and other religious orders, as well as the great Portuguese merchants interested in extending their businesses, directly and legally, to the Castilian possessions.

However, to face opposition to his pretensions, Filipe II decided to take the Portuguese throne by military means, having entered in Portugal as a lawful king at the end of 1580. During the Cortes de Tomar, in April 1581, he is finally invested with the Lusitanian Majesty, in a ceremony that in all aspects respected the protocol of the Portuguese monarchy. This would be the first of several actions taken by Filipe II - now also Filipe I of Portugal - "to show and to make accept that his government was so Portuguese and so favorable to Portuguese interests as those of his predecessors", using Magalhães' words (1993, p. 566). In fact, the monarch governed his empire - now with a truly planetary scale - from Lisbon, where he stayed for two years, with no significant changes in the collective trajectory of the Portuguese people experience.

Despite his policy of adapting to local balances - which, as has already been shown, served to legitimize the immensity of his power - Filipe "is persuaded of his divine mission as sovereign" striving "constantly for imposing an unconditional absolutism" (Hoftätter \& Pixa, 1987, p. 12). Good examples of this kind of behavior were: his violent actions to repress Protestantism and autonomist aspirations in many of his domains in Europe; the constitution of the Invincible Armada against Elizabeth I of England; the pursuit of America's implacable conquest with the extermination of Amerindian populations. All these episodes touched the Hell that completes the triptych in which Filipe II interpreted the diversity of the world. Therefore, we must take into account the ideological position of absolutism that marked Filipe II's governance, in order to complete the reading of the relation between the "Garden of Delights" and the conception of the world with which the monarch felt the diversity. Indeed, the diversity of the world was, simultaneously, the target of his admiration for all the new discoveries, the point to establish the philosophy of structural equilibrium for his extensive power, and also something that should be ideologically dominated by force, even if it were necessary to use the language of violence.

These three different dimensions of Filipe's relationship with diversity - that emerge from the use of the three analysis categories proposed by Mukarovsky in the interpretation of the interaction of Bosch's piece of art and the monarch's conception of the world 
- once linked, suggest us to observe a man penetrated by complex contradictions and, at the same time, a man able to elaborate the synthesis of his space and his time. Filipe II pontificates in the Iberian space of Portugal and Spain, precisely the two kingdoms that the decades before his reign had inaugurated a new cycle in the historical course of humanity: a cycle in which the world opens itself to its own diversity through the first great intercontinental navigations. As Erlichman (2010) points out, he is also the one who accomplishes the convergence of the two immense overseas empires that these nations, the greatest powers of the time, had founded in the most diverse places of the world recently discovered. Who better than Filipe II could embody the web of inevitable contradictions that lay in such an admirably new world?

However, it is necessary to take into account that the coexistence between the paradise imagined in a new place to discover, the integrationist equilibrium of the garden of earthly delights and the hell of domination by force did not constitute an innovation or an exclusive of the practices of this sovereign, especially when analysing the historical relationships between power holders and diversity in the world. In fact, this contradictory triad of expectations and attitudes towards the diverse has been incessantly replicated since the first encounters of the human with the unknown. What constituted an exceptional situation in the space / time of Filipe II was the fact that the noetic discovery, the philosophy of integration and the ideology of domination, as conceptions of relation with a diverse world, have been enlarged on the planetary scale. As we all know, it was only possible because first it happened the European overseas expansion, pioneered by Portuguese and soon followed by Spaniards.

It is in this $16^{\text {th }}$ century scenario, in which the true dimension of the world is revealed to mankind and the continents are for the first time in History permanently linked by overseas commerce, that some authors (Erlichman, 2010; Modelski, 2005; Rodrigues \& Devezas, 2009) interpret the first episode of the evolutionary narrative of globalization. In fact, the theorization of Modelski (2005) on the long cycles of global politics recognizes the Iberian expansion as the main cause to the constitution of the first global leadership nucleus, empowered by the production and communication of knowledge about the diversity of the world. In this regard, Fernández-Armesto points out, concerning the great navigations of Colombo or Vasco da Gama, that "in the subsequent history of the world, very little can be understood outside this context" (2010, p. 507). In fact, from these boundless feats, we witnessed a process of structural transformation in which the world opened up to its own diversity, and at the same time the European colonial empires were built in America, Asia and Africa.

\section{INTERCULTURAL COMMUNICATION AND MEMORY DEFRAGMENTATION}

In this point of the essay, it seems to make sense to remind an idea postulated by Canclini about the cross-stories that the dynamics of the world's decompartmentalization $^{3}$ left us: the tensions between globalizing forces and the interculturality dynamics

\footnotetext{
${ }^{3}$ This concept prevails today as an alternative to the concept of "Discoveries", since this was considered too Eurocentric.
} 
"can be conceived as a relation between the epic and the melodrama" (2007, p. 32). Like Canclini, other authors (Dussel, 2012; Mignolo, 2000) also recognize strong limitations to dualistic models of reality interpretation. Such models, based on dichotomized readings, have contributed to the construction of a fragmented memory, incompletely useful for the understanding of the past, as well as for the understanding of the tensions and conflicts that characterize the present time. As an example, it will be possible to show how the memory of Portuguese colonialism has been created:

although the memory of colonization is fairly present in the narratives of both parts, in fact the meanings attributed to it are distinct. For example, on the side of the former colonizer there is a forgetfulness or non-recognition of the most violent effects of colonial expansion (...). On the part of the ex-colonized are the violent effects of colonial action that become more evident in the analyzed records, emphasizing the more oppressive aspects of colonialism (slavery, massacres). (Macedo, 2013, pp. 273-274)

As an alternative to the dualistic models, we propose that the critical reading of the processes of interaction between different cultures arising from European overseas expansion should adopt a broader model of analysis. Departing from the three conceptions on the diversity of the world which Filipe II so well embodies and which Bosch's triptych so well symbolizes, we propose discovery, integration and domination as categories to understand the tension between globalization and interculturality. Once epic and melodrama are the result of opposing readings of domination processes, what we expect from this broader proposal is the establishment of a multidimensional analysis model. So, with the adoption of this model it will be possible to accept the most diverse perspectives, contributing to the construction of a heterological narrative, with no Nationalisms and ideological appropriations. The same is to say that, with this model, we intend to take another step towards a defragmentation of memory that allows the opening to other possibilities of retelling the past ${ }^{4}$. As Borges Coelho (2013) points out, the past should not be approached as a closed time, with a definitive history; on the contrary, it must frequently be revisited and its study must be a work under permanent reformulation.

However, in order to achieve this objective, the proposed model should be tested in accordance with two fundamental assumptions, which are presented below. The first assumption is that this model of analysis cannot be confined to a strictly historiographical approach, despite its relevance to the understanding of the past. For this reason, the precious contributions of History must be taken into account, but not constituting the exclusive basis of a critical discourse on the opening of the world to its own diversity. Any process of structural transformation is, by its very nature, multidimensional, admitting aspects as varied as political, economic, social or cultural, which, in turn, branch out into specific components such as Geo-strategy and International Relations, Agriculture and

\footnotetext{
${ }_{4}$ On other possibilities of retelling the past, it is Khan (2016) who refers to the "post-memory duty", that is, the possibility of retrieving experiences and narratives told by people who have kept silent. In the opinion of the author, if the "post-memory duty" is not cultivated, this heritage will not leave any evidence for later.
} 
Commerce, Anthropology and Ethnography or Religion and Language. So, the need to knit a multidisciplinary discourse in the different meshes given by the different glances is only possible if we take into account the diverse disciplines of the social and human sciences. In this sense, the opening of the world to its own diversity should be framed in the broader perspective of intercultural communication, as understood by Cabecinhas \& Cunha (2008), in order to accommodate the different readings triggered by their multiple dynamics of relation between people, goods and ideas. From this perspective we could interpret a process reality in which participants from various ethnic groups, religions and cultures intersect, not forgetting their inequality conditions, the boundaries between them and, finally, the enormous distance that separates their real interrelations from their supposed mixture. It is important to stress, therefore, that in this perspective, the object of study will be not so much the historical fact, but rather the process of intercultural communication that occurs in the context of this same fact.

It should be stressed, however, that the perspective of intercultural communication does not dispense a serious approach to the issue of otherness. For this very reason, we suggest a return to the work of Todorov (1991), who argues that alterity can only be understood when one observes the interdependences between its three dimensions: the axiological dimension, the praxiological dimension and the epistemic dimension. In the axiological dimension, judgments of value in relation to each other come into play. The concrete actions towards this other - assimilation, submission or indifference, for example - are situated in the praxiological dimension. Finally, the level of knowledge about the identity of the one different of me defines the epistemic dimension. However, it should be noted that the axiological dimension of the understanding of the relations of otherness must be associated with the drive of domination; with its praxiological dimension, we could relate the various processes of integration; finally, its epistemic dimension must be linked to the discovery experience.

It is for this reason that the approach to intercultural communication should not be confounded with the contemporary approach to cultural dialogue, since the latter is, in Todorov's words (1991, p. 246), "a dialogue where nobody has the last word, where none of voices reduces the other to the status of a mere object, and where one takes advantage of its exteriority to the other". Although well-intentioned, the view of the dialogue of cultures, by excluding the communicational processes in which one side places itself in a position of superiority (or inferiority) relative to the other, compromises the understanding of the main dynamics of interaction between different cultures. As it is amply documented, the successes and failures of the process of opening the world protagonists, over more than five centuries of history, have been largely due to the different forms of communication with the most diverse partners.

The second assumption for the use of this model, that serves to reinforce the importance of the first, departs from the idea defended by Ferro (2004) that there is no historical truth valid for all. On each event, every people or nation overlaps - when they do not oppose - different determinations, not being certain that one has more legitimacy than the others. The need to analyse the openness of the world to its own diversity must 
be fulfilled not only confronting the various points of view produced in Europe, but also taking into account the traditionally silenced perspectives, banned for a long time, produced in Africa, America or Asia.

However, in addition to being less numerous and less widespread, these non-European approaches often acquire, in Ferro's (2004, p. 16) understanding, a "therapeutic function"; the same is to say that, in relation to Europe, the societies of the rest of the world decolonize their own history with the same instruments previously used by the colonizer. In this way, by selectively constructing a reverse memory of that which has also been selectively developed by European interests, new versions of history seek to reconcile these societies with their own past ${ }^{5}$.

In any case, as Said affirms, the interpretation of the past of overseas colonialism presupposes the opposition of "two different perspectives (...) one linear and dominating, the other counterfactual and often nomadic (sic)" (1993/2011, p. 29). Although the author is inclined to the second perspective, he notes that, whether it is told by those who colonized or by those who were colonized, no story of this type of experience is edifying.

In spite of these observations, neither the understanding of Ferro nor the understanding of Said are oriented in the sense that this past should not be analysed; on the contrary, both authors suggest that the narratives on overseas expansion and the European colonial empires must be recomposed, integrating events and places that have escaped memory (in the case of Ferro), or integrating the perspective given nowadays by Postcolonial approach (in Said's case).

In the same line of thought, it is McMillin (2009) who argues that in order to address the current globalization, it is necessary to scrutinize contemporary history and practices in the simultaneous temporal, spatial and ideological map given by postcolonial studies. Initially conceived as a methodology, rather than as a theory, postcolonial studies have been developed to analyse how societies once colonized have adapted to the imperial discourse, as well as the impressions bequeathed by colonialism in their culture. The relevance of this approach is emphasized by the author because the consequences of colonialism - which are felt to this day - are collectively shared by the societies that lived it. Hence, the need to take it into account when we intend to study the current conditions of contemporary societies with a colonial past.

However, it should be noted that post-colonialism is not free from weaknesses, as Almeida (2002) has pointed out. Having emerged at the cross-exercise of literary criticism and cultural studies - in turn, heirs to critical theory and post-structuralism - postcolonialism was an alternative approach to Western knowledge standards, especially regarding historiographical production and the study of social identities. In addition to the rejection of all the master narratives and Eurocentrism emanating from them, the postcolonial approach repudiates dichotomies as "center / periphery" or "first world / third world" allegedly created by colonialism, giving room to a new discursive constitution of

\footnotetext{
5 Ferro (2004) refere, a título de exemplo, que a história ensinada às crianças africanas tende a glorificar o esplendor dos grandes impérios existentes no seu continente antes da chegada de europeus, por contraposição ao atraso e à decadência da Europa feudal da mesma época.
} 
the world. Hence, the most radical post-colonialism takes the risk of replacing the former colonizer's unique truth with the ex-colonized's unique truth, thus contributing to the strengthening of the "Resentment School" referred to by Bloom (1997, p. 31).

By the way, the second assumption tries to strengthen the perspective of intercultural communication, with no refusal of Eurocentrism or post-colonial "therapeutic" discourses. Such a refusal would lose sight to the proposal for which it is intended to contribute: the defragmentation of the memory.

\section{ConcLusion}

Considering that the crossing of the independent present with the colonial past generates mistakes of difficult resolution which result in the production of dual narratives, incapable of interpreting the whole reality by their own, it was presented a proposal of an alternative analytical model for the critical reading of the communication dynamics between cultures since the world became global. Indeed, the world in which we live today is the heir of the best and the worst of European overseas expansion and colonial empires. And this was undoubtedly a movement which, having contributed to the world's opening to its own diversity naturally could not control it.

The proposal presented here should be developed from the perspective of intercultural communication departing from the interconnection of the various contributions, the various perspectives and the various voices involved in this movement, adopting for this purpose three analytical categories inspired by the three conceptions on the diversity of the world that Filipe II interpreted in the Garden of the Delights: the discovery, the integration and the domination.

However, the perspective of intercultural communication cannot be conceived outside a framework of dispute between unequal forces, once in all processes of communication between cultures there are always stronger interlocutors and weaker interlocutors. Otherness is losing ground as a characteristic of our time, while the past was marked by the lack of recognition of the other as a human. The proposal presented here, while assuming the ambition of being an alternative model for analyzing the relation between globalizing forces and the dynamics of interculturality, must be understood without any kind of messianism. Rather, it should be understood as a possible instrument of memory defragmentation that helps us to better understand the growing structural crisis and conflict that we are experiencing today. This is because the world, diverse as it is, will never be a Paradise; But it also does not have to be the violent Hell of Bosch's triptych."

Traduzido por Lurdes Macedo 


\section{Bibliographic REFERENCES}

AAVV (2006). A Grande História da Arte - Renascimento e Maneirismo (3). Público.

Almeida, M. V. (2002). O Atlântico pardo. Antropologia, pós-colonialismo e o caso "lusófono". In C. Bastos; M. V. Almeida \& B. Feldman-Bianco(Eds.), Trânsitos Coloniais: Diálogos Críticos Luso-Brasileiros (pp. 2337). Lisbon: Imprensa de Ciências Sociais.

Bloom, H. (1997). O cânone ocidental. Lisbon: Temas e Debates.

Borges Coelho, J. P. (2013). Politics and contemporary history in Mozambique. A set of epistemological notes. Kronos, 39(1), 20-31.

Bosing, W. (2003). Hieronymus Bosch. Entre o Céu e o Inferno. Köln: Tashen.

Bouza, F. (2005). D. Filipe I. Coleção Reis de Portugal. S/l: Círculo de Leitores e Centro de Estudos dos Povos e Culturas de Expressão Portuguesa.

Cabecinhas, R. \& Cunha, L. (2008). Da importância do diálogo ao desafio da interculturalidade. In R. Cabecinhas \& L. Cunha, Comunicação Intercultural. Perspetivas, Dilemas e Desafios (pp. 7-12). Oporto: Campo das Letras.

Canclini, N. G. (2007). A globalização imaginada. São Paulo: Editora Iluminuras.

Dussel, E. (2012). Transmodernity and interculturality: an interpretation from the perspective of philosophy of liberation. Transmodernity, 1(3), 28-59.

Erlichman, H. J. (2010). Conquest, tribune and trade: the quest for precious metals and the birth of globalization. New York: Prometheus Books.

Fernández-Armesto, F. (2010). A expansão portuguesa num contexto global. In F. Bethencourt \& D.R. Curto, A Expansão Marítima Portuguesa, 1400-1800 (pp. 491-524). Lisbon: Edições 70.

Ferro, M. (2004). Comment on raconte l'histoire aux enfants à travers le monde. Paris: Éditions Payot.

Hofstätter, H. H. \& Pixa, H. (1987). História universal comparada - De 1550 a 1900 (Volume VIII). Lisbon: Resomnia Editores.

Joly, M. (1999). Introdução à análise da imagem. Lisbon: Edições 70.

Khan, S. (2016). A pós-memória como coragem cívica. Palavra de ordem: resistir, resistir, resistir. Comunicação e Sociedade, 29, 353-364. doi: http://dx.doi.org/10.17231/comsoc.29(2016).2424

Macedo, I. (2016). Os jovens e o cinema português: a (des)colonização do imaginário? Comunicação e Sociedade, 29, 271-289. doi: http://dx.doi.org/10.17231/comsoc.29(2016).2420

Magalhães, J. R. (1993). Filipe II (I de Portugal). In J. R. Magalhães (Ed.), No Alvorecer da Modernidade (pp. 563-570). Coleção História de Portugal. Lisbon: Editorial Estampa.

McMillin, D. C. (2009). Mediated identities. Youth, agency a globalization. New York: Peter Lang Publishing.

Mignolo, W. (2000). Local histories / Global designs: coloniality, subaltern knowledges, and border thinking. Princeton: Princeton University Press.

Modelski, G. (2005). Long-term trends in world politics. Journal of World-Systems Research, 11(2), 195-206.

Mukarovsky, J. (1997). Escritos sobre estética e semiótica da arte. Lisbon: Editorial Estampa. 
Portús, E. Z. (Ed.) (2008). O guia do Prado. Madrid: Museo Nacional del Prado.

Quina, J. (Ed.) (2005). Museu do Prado. Colecção Museus do Mundo. S/I: Edições Planeta Agostini.

\section{FinANCIAL SUPPORT}

This article was written under the postdoctoral fellowship awarded by the Foundation for Science and Technology, funded by the Portuguese State and the European Union, under Reference SFRH / BPD / 103706/2014

\section{BIOGRAPHICAL NOTE}

Lurdes Macedo did her Ph.D in Communication Sciences at University of Minho. She is also a researcher at the Communication and Society Research Centre at the same university. She take a part of the research project team "identity narratives and social memory: the (re) construction of the Lusophonia in intercultural contexts", between 2009 and 2013. She was an invited researcher at the Lusophone Studies Center of the Mackenzie Presbyterian University of São Paulo (Brazil) in 2009, 2010, 2011 and 2012. She was also an invited researcher at the Radio, Television and Film Department at the University of Texas at Austin (USA) in 2011. She was co-editor of the Anuário Internacional de Comunicação Lusófona [International Yearbook of Lusophone Communication] in 2010 and 2011, as well as of the e-book Interfaces da Lusofonia in 2014. She published over 20 articles in national and international scientific journals. She was invited assistant of Higher Education School of the Polytechnic Institute of Viseu between 2009 and 2012. She is currently Assistant Professor at Lusophone University of Porto and at Polytechnic University at Maputo (Mozambique). She worked several times as a guest professor in four Brazilian universities - University of São Paulo, University of Sao Paulo, Mackenzie Presbyterian University of São Paulo and the Federal University of Minas Gerais - between 2009 and 2012. In addition to the activity as a university lecturer and researcher, she integrated interdisciplinary teams in consulting projects, particularly development projects.

E-mail:mlmacedo7ı@gmail.com

Centro de Estudos de Comunicação e Sociedade

Universidade do Minho, Campus de Gualtar, 4710-057, Braga, Portugal

* Submitted: 15-10-2016

* Accepted: 21-01-2017 